\title{
Change in physicochemical properties, phytoestrogen content, and antioxidant activity during lactic acid fermentation of soy powder milk obtained from colored small soybean
}

\author{
Chung Eun Hwang, Kye Man Cho, Su Cheol Kim, Ok Soo Joo* \\ Department of Food Science, Gyeongnam National University of Science and Technology, Jinju 52725, Korea
}

\section{유색 소립콩 분말 두유의 젖산발효 중 이화학적 특성, 식물성 에스트로겐 및 항산화 활성 변화}

\author{
황정은 · 조계만 · 김수철 · 주옥수* \\ 경남과학기술대학교 식품과학부
}

\begin{abstract}
This study investigated the changes in physicochemical properties, total phenolic and phytoestrogen (isoflavone) contents, and antioxidant activity, including 2,2-diphenyl-1-picrydrazyl (DPPH) and 2,4,6-azinobis (3-ethylbenzothiazoline- 6-sulfonic acid) (ABTS) radical activities and ferric reducing antioxidant power (FRAP), during the lactic acid fermentation of soy powder milk (SPM) with colored small soybean (CSS) by the potential probiotic Lactobacillus plantarum P1201. The pH decreased, while viable cell numbers and $\beta$-glucosidase activities gradually increased during lactic acid fermentation of SPM. The total isoflavone content of Pungsannamul soybean was higher than that of other CSS cultivars. The isoflavone glycoside (daidzin and genistin) contents decreased whereas, corresponding isoflavone aglycone (daidzein and genistein) content significantly increased during the fermentative processing. In particular, fermented SPM prepared from Pungsannamul soybean showed highest daidzein (87.37 $\mu \mathrm{g} / \mathrm{g}$ ) and genistein $(51.29 \mu \mathrm{g} / \mathrm{g})$ after fermentation for $60 \mathrm{~h}$. Total phenolic contents (TPCs) of Dawon soybean was higher than that of other CSS cultivars. TPC also increased marginally from $1.44-2.92 \mathrm{mg} / \mathrm{g}(0 \mathrm{~h})$ to $1.79-3.03$ $\mathrm{mg} / \mathrm{g}(60 \mathrm{~h})$ during lactic acid fermentation of SPMs with CSS. Finally, fermented SPM extracts possessed potent DPPH and ABTS radical scavenging activities and FRAP effects with change from 28.7-40.6 to 90-95.3\%, 25.1-42.3 to $51.4-82.8 \%$, and $0.73-1.54$ to $0.98-1.79\left(O_{593} \mathrm{~nm}\right)$, respectively in pre-and post-fermented samples. Therefore, fermented SPM might contribute to enhance the value of CSS.
\end{abstract}

Key words : colored small soybean, Lactobacillus plantarum P1201, soy powder milk, isoflavone, antioxidant activity

\section{서 론}

콩(Glycine $\max$ )은 예로부터 오곡의 하나로 꼽혀 왔으며, 쌀을 주식으로 하는 동양인에게는 쌀에 부족한 단백질과 필수지방을 공급 받을 수 있는 유용한 작물이다(1). 또한

*Corresponding author. E-mail : osjoo@gntech.ac.kr Phone : 82-55-751-3273, Fax : 82-55-751-3279

Received 1 August 2018; Revised 20 August 2018; Accepted 30 August 2018.

Copyright (c) The Korean Society of Food Preservation. All rights reserved.
콩은 종류와 생김새 그리고 백립 중 무게에 따라 콩 품종과 쓰임새가 다르게 분류된다. 세부적으로는 극대, 대, 중, 소 및 극소립으로 구분 짓고 있으며, 검정콩은 극대립(28-29 $\mathrm{g})$, 장류용 노란콩은 대립 또는 중립 $(20-25 \mathrm{~g})$, 특히 우리나 라에서 대부분 콩나물 형태로 소비가 되는 나물콩은 소립 (8-12 g)으로 분류되어있다(2). 한편 콩에 함유된 유효성분 (polyphenol, isoflavone 및 protein)은 골다공증, 각종 암 예 방 및 콜레스테롤 저하 등의 효과가 알려져 있으며 $(3,4)$, 인체에 유해한 중금속 이온들과 결합해 체외로 쉽게 배설시 키는 기능이 탁월하여 동양인의 식재료로 오랜 시간 함께 사용 되어져 왔다(5). 
Isoflavone은 콩에 함유 되어있는 가장 대표적인 기능성 화합물로서 estrogen으로 불리는 여성 호르몬과 화학구조 가 매우 흡사하고 특히 여성 호르몬이 더 이상 생산되지 않는 폐경기 여성들에게는 아주 중요한 호르몬 공급원이 다. Isoflavone은 크게 4가지 그룹으로 나뉘고 12가지 화합 물이 존재하며 당과 결합된 배당체 중 glycosides(daidzin, genistin, glycitin) 형태는 24-25\% 정도이며 malonyl-glycosides (malonyl-daidzin, genistin, glycitin) 형태는 70-80\% 정도 함 유되어 있다(4). 한편 acetyl-glycosides(acetyl-daidzin, genistin, glycitin) 형태는 약 3-5\%정도 존재하며 비배당체인 aglycones(daidzein, genistein, glycitein) 형태는 약 1-2\% 정 도로 콩에 극미량 함유되어 있는 것으로 보고되었다(1). 특히 비배당체 isoflavone은 콩 뿐만 아니라 여러 콩 가공식 품 내에서도 적은 양이 존재를 하며 미량으로도 배당체 isoflavone에 비해 생체 내에서 우수한 생리활성을 나타내 는 연구 결과가 보고되었다(6,7). 특히 주요 활성 물질로는 daidzein 및 genistein으로 알려져 있고 이들 화합물은 유방 암과 전립선 암 등의 암세포 증식을 억제하고 나아가 뼈 건강에도 탁월한 효과가 있는 것으로 최근 연구 결과에 의해 밝혀진바 있다(7). 한편 Cho 등(8)은 콩 품종과 종자의 껍질 색에 따라 수용성 phenolics 함량과 항산화 활성의 차이가 있음을 보고하였고 Choi 등(5)과 Ewe 등(9)은 유산 균을 이용한 두유 발효 시 발효 과정 중 유산균이 생성하는 젖산과 가수분해 효소활성에 따라 비배당체 형태인 daidzein과 genistein이 크게 증가함을 보고하여 발효 두유의 기능성을 입증하였다.

유산균은 생균제로 널리 사용이 되고 있으며 소화 흡수 를 돕고 장내 부패세균의 성장을 억제하고 혈중 콜레스테롤 저하 등 인간에게 다양한 건강기능을 가져다주는 대표적인 미생물이다. 발효 두유 혹은 콩 요구르트는 유당불내증의 원인인 유당이 없는 반면 각종 비타민류, 불포화지방산, isoflavone 등이 함유되어 있어 유산균 증식에도 좋은 환경 이 되며(10), 젖산발효를 통해 비소화성 과당류 분해와 젖산 생성으로 인해 적당한 산미와 영양성분이 강화된 발효유 중 하나다(11). 특히 probiotics와 prebiotics를 동시에 함유하 는 식품으로 경제적인 측면에서도 일반 요구르트 및 두유 보다 우수하다(10). 한편 국내의 경우 콩을 이용한 연구 결과들은 수 없이 많으나 장류콩 또는 검정콩에 의한 결과 만이 있을 뿐 소립콩을 이용한 발효 두유에 관한 연구는 매우 부족한 실정이다.

따라서 본 연구에서는 종피 색이 다른 소립콩 품종인 풍산나물콩, 녹채콩, 갈채콩 및 다원콩 분말에 생균제제능 이 뛰어난 Lactobacillus plantarum P1201 유산균을 이용하 여 발효 두유를 제조하였으며 발효 시간에 따른 생리활성 및 식물성 에스트로겐 함량 변화를 비교 분석하였다.

\section{재료 및 방법}

소립콩 품종, 유산균, 배지 및 시약

본 연구에 사용된 유색 소립콩인 풍산나물콩(노란색, $10.25 \mathrm{~g} / 100 \mathrm{ea}$ ), 녹채콩(녹색, $9.73 \mathrm{~g} / 100 \mathrm{ea}$ ), 갈채콩(갈색, $9.14 \mathrm{~g} / 100 \mathrm{ea}$ ) 및 다원콩(검정색, $11.26 \mathrm{~g} / 100 \mathrm{ea}$ )은 경상남 도 밀양군 농촌진흥청 국립식량과학원 남부작물부에서 2013년에 재배 및 수확된 것을 공급받아 사용하였다(Fig. 1). 두유 발효를 위한 유산균은 최근 보고된 결과를 바탕으 로 두유 발효 중 젖산 생성력과 우수한 $\beta$-glucosidase 활성에 의해 total phenolics와 비배당체 isoflavone 함량을 크게 증 가시켜 유효성분 강화 발효두유 제조에 최적인 $L$. plantarum P1201 균주를 사용하였다(12,13). 미생물 배양 배지로는 Lactobacill MRS broth(MRS, Becton, Dicnson Co., Sparks Glencoe, MD, USA)를 사용하여 유산균 배양에 사용 하였다. 12종류의 isoflavone 중 비배당체(daidzein, glycitein, 및 genistein)는 Sigma-Aldrich(St. Louis, MO, USA)에서 구입하였고 배당체 중 daidzin, genistin, glycitin 은 Indofine(Hillsborough, NJ, USA)에서 구입하였으며 malonylglycosides 및 acetylglycosides 배당체 형태는 LC Laboratories(Woburn, MA, USA)에서 구입하였다. 한편 $\beta$ -glucosidase 활성에 사용된 기질인 p-nitrophenyl $\beta$-Dglucopyranoside(p-NPG)는 Sigma-Aldrich사에서 구입하여 본 연구에 사용하였다. Glacial acetic acid, Folin-Cialteu phenol reagent, 2,2-diphenyl-1-picrydrazyl(DPPH), 2,4,6azinobis(3-ethyl-benzothiazoline-6-sulfonic acid)(ABTS)와
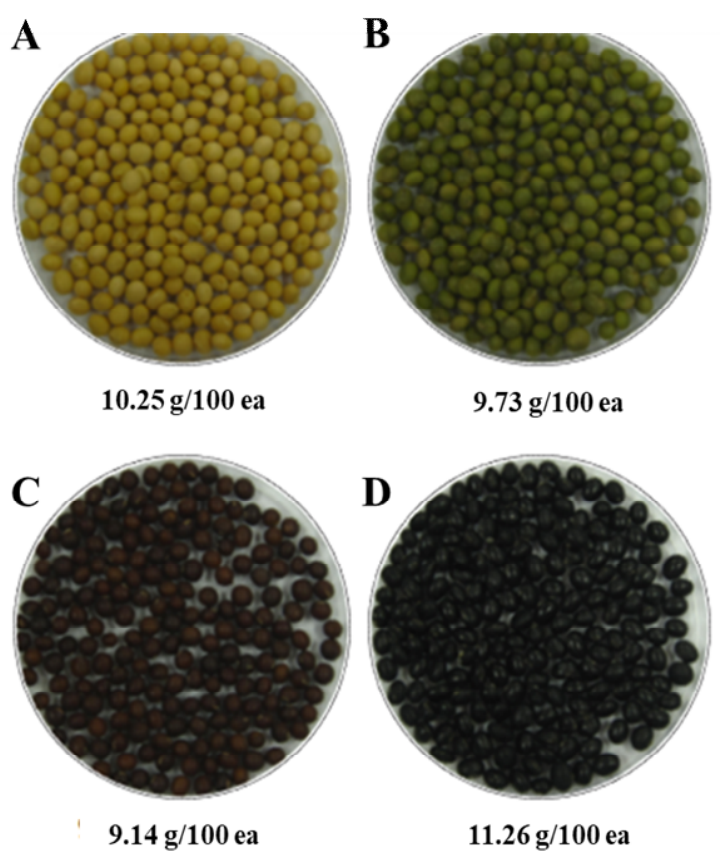

Fig. 1. Photograph and comparison of the seed weight of colored small soybean cultivars.

A, Pungsannamul soybean; B, Nokche soybean; C, Galche soybean; D, Dawon soybean. 
ferric reducing antioxidant power(FRAP) 환원력 측정은 2,4,6-tripyridyl-s-triazine(TPTZ) 는 Sigma-Aldrich 제품을 구 입하여사용하였다. Methanol, acetonitrile 및 water는 J.T.Baker사(Philipsbug, NJ, USA)에서 구입하여 사용하였 고 그 외 나머지 기타 시약은 필요에 따라 특급 혹은 1 급을 구입하여 사용하였다.

\section{두유 제조 및 젖산발효}

유산균 종균배양은 MRS 액체배지에 접종하여 $35^{\circ} \mathrm{C}$ 에서 48 시간 배양하여 사용하였다. 한편 유색 소립콩 분말은 콩 $1,000 \mathrm{~g}$ 에 물을 3 배 가수한 후 $25 \pm 3{ }^{\circ} \mathrm{C}$ 에서 6 시간 불린 후 물기를 제거하고 $100^{\circ} \mathrm{C}$ 에서 1 시간 증자하고 $55 \pm 2^{\circ} \mathrm{C}$ 에서 3 일간 열풍건조한 후 100 mesh 정도로 분말화하여 준비하 였다. 두유 제조는 $250 \mathrm{~mL}$ 유리병에 유색 소립콩 분말 10 $\mathrm{g}$ 과 발효 기질로서 설탕 $5 \mathrm{~g}$ 을 칭량한 후 물 $100 \mathrm{~mL}$ 를 첨가 및 혼합하여 $121^{\circ} \mathrm{C}$ 에서 15 분 살균하여 제조하였다. 이 후 상온 $\left(15-25^{\circ} \mathrm{C}\right)$ 으로 적당히 식힌 후 종균 배양액을 $5.0 \%(\mathrm{v} / \mathrm{v})$ 접종하고 $35^{\circ} \mathrm{C}$ 에서 60 시간 정치 발효시켜 발효 두유를 최종적으로 제조하였으며 12 시간 간격으로 시료를 채취하여 본 연구에 사용하였다(11).

\section{이화학적 특성}

$\mathrm{pH}$ 는 $\mathrm{pH}$ meter(model 3510 , Jenway, Essex, UK)를 사용 하여 측정하였다. 총산은 중화적정법으로 시료 $1 \mathrm{~mL}$ 를 $\mathrm{pH}$ $8.3 \pm 0.1$ 까지 중화시키는데 소비된 $0.1 \mathrm{~N} \mathrm{NaOH}$ 의 양을 구하 고 젖산으로 환산하였다. 생균수는 멸균생리식염수로 단계 별 희석하여 MRS 평판배지에 도말한 후 $30^{\circ} \mathrm{C}$ 에서 48 시간 배양 후 나타난 집락수를 계수하였다. 발효 중 $\beta$-glucosidase 활성 측정은 Hwang 등(12)의 방법을 약간 변형하여 수행하 였다. 우선 각각의 소립콩 발효 두유 $5 \mathrm{~mL}$ 에 $5 \mathrm{mM}$ 인산나트 륨 완충용액(pH 7.0) $50 \mathrm{~mL}$ 를 첨가 및 혼합하고 $4^{\circ} \mathrm{C}$ 에서 30 분간 $4,000 \mathrm{rpm}$ 의 속도로 원심 분리한 후 상등액을 0.45 $\mu \mathrm{m}$ 필터로 여과하여 조효소를 제조하였다. 조효소 $250 \mu \mathrm{L}$ 에 $100 \mathrm{mM}$ 인산나트륨 완충용액 $(\mathrm{pH}$ 7.0) $250 \mu \mathrm{L}$ 를 가한 후 $37^{\circ} \mathrm{C}$ 에서 15 분간 예비 반응을 진행하였다. 여기에 인산 나트륨 완충용액 $(\mathrm{pH} 7.0)$ 함유 $\mathrm{p}-\mathrm{NPG}(5 \mathrm{mM}) 250 \mu \mathrm{L}$ 를 가하 여 다시 $37^{\circ} \mathrm{C}$ 에서 30 분 반응시킨 후 탄산나트륨 용액(200 $\mathrm{mM}) 250 \mu \mathrm{L}$ 를 가하여 효소반응을 종결시키고 분광광도계 를 사용하여 $405 \mathrm{~nm}$ 에서 방출된 p-nitrophenol의 양을 측정 하였다. 이때 $\beta$-glucosidase 활성의 효소단위인 1 unit은 상 기 조건에서 1 분당 $\mathrm{p}-\mathrm{NPG}$ 의 $1 \mathrm{\mu M}$ 을 유리하는 효소 양으로 정의하였다.

\section{추출물 제조 및 수율 계산}

발효 두유 추출물은 Hwang 등(11)의 방법에 준하여 제조 하였다. 즉, 동결건조 분말 $1 \mathrm{~g}$ 에 10 배의 $50 \%$ 메탄올을 가하고 상온에서 12 시간 추출하였다. 추출물은 원심분리기
(MF-530, Hanil, Seoul, Korea)를 이용하여 3,000 rpm에서 20 분간 원심분리 하고, 상등액을 취하여 $0.45 \mu \mathrm{m}$ membrane filter(Dismic-25CS, Toyoroshikaisha, Ltd., Tokyo, Japan)로 여과한 후 추출물의 최종 농도를 $100 \mathrm{mg} / \mathrm{mL}$ 로 제조하여 total phenolics와 isoflavone 함량 및 항산화 활성 측정을 위한 시료로 사용하였다. 한편 추출물의 수율 계산은 추출 전의 각각의 콩 분말의 중량과 동결건조 후 건조 중량에 대해 백분율(\%)로 계산하였으며 아래의 식에 대입하였을 시 본 연구의 추출물 수율은 평균 $70 \%$ 로 나타났다.

$$
\text { 추출물 수율 }(\%)=\frac{\text { 콩 분말의 중량 }(\mathrm{g})}{\text { 동결건조 후 건조 중량 }(\mathrm{g})} \times 100
$$

\section{Total phenolics 함량}

Total phenolics 함량은 Lee 등(13)의 방법과 동일하게 수행하였다. 발효 두유 추출물 $0.5 \mathrm{~mL}$ 를 시험관에 분주하고 $25 \% \mathrm{Na}_{2} \mathrm{CO}_{3}$ 용액 $0.5 \mathrm{~mL}$ 를 첨가하여 $3 \mathrm{~min}$ 정치시켰다. 다시 $2 \mathrm{~N}$ Folin-Ciocalteu phenol 시약 $0.25 \mathrm{~mL}$ 를 첨가하여 혼합한 다음 $30^{\circ} \mathrm{C}$ 에서 1 시간 동안 정치시켜 발색시켰다. 발색된 청색을 분광광도계(Spectronic 2D, Thermo Fisher Scientific, Inc., Waltham, MA, USA)를 사용하여 $750 \mathrm{~nm}$ 에 서 흡광도를 측정하였다. 이때 total phenolics 함량은 tannic $\mathrm{acid}$ 를 이용하여 작성한 표준곡선으로부터 함량을 산출 하 였다.

\section{Isoflavone 함량}

Isoflavone 함량 분석은 최근 보고된 Hwang 등(14)의 방 법에 준하여 high performance liquid chromatography(HPLC, Agilent 1200 series, Agilent Co., Forest Hill, Vic, Australia) 로 분석하였다. 분석 column은 Lichrophore $100 \mathrm{RP} \mathrm{C}_{18}$ column $(4.6 \times 250 \mathrm{~mm}, 5 \mu \mathrm{m}$, Merck, Germany)을 사용하였고 이동상 용매는 $0.2 \%$ glacial acetic acid in water(A line)와 $0.2 \%$ acetonitrile in glacial acetic acid(B line)로 분석하였다. 이동상 조건은 A line 기준으로 0 분- $100 \%, 15$ 분-90\%, 25분 $-80 \%, 35$ 분-75\%, 45 분-65\% 및 50 분-65\%로 유지하였다. 시 료는 $20 \mu \mathrm{L}$ 를 주입하였으며, 이동상은 $30^{\circ} \mathrm{C}$ 에서 분당 1 $\mathrm{mL}$ 의 유속을 유지하였으며 diode array detector(DAD)를 사용하여 UV $254 \mathrm{~nm}$ 에서 검출하였다.

\section{$\mathrm{DPPH}$ 라디칼 소거 활성}

$\mathrm{DPPH}$ 라디칼 소거 활성은 Joo 등(15)의 방법에 따라 수행하였다. DPPH 에탄올 용액 $0.8 \mathrm{~mL}$ 와 각 추출물 0.2 $\mathrm{mL}$ 를 가하고 충분히 혼합한 후 암실에서 30 분 방치 후 분광광도계를 사용하여 $523 \mathrm{~nm}$ 에서 흡광도를 측정하였다. 음성대조구 실험은 두유 추출물 대신 메탄올 $0.2 \mathrm{~mL}$ 를 취하 여 실험하였으며 실험구와 음성대조구의 흡광도를 구하여 백분율(\%)로 나타내었다. 


\section{ABTS 라디칼 소거 활성}

$\mathrm{ABTS}$ 라디칼 소거 활성 역시 Joo 등(15)의 방법에 준하 여 측정하였다. $7 \mathrm{mM} \mathrm{ABTS}^{++} 5 \mathrm{~mL}$ 과 $2.45 \mathrm{mM} \mathrm{K}_{2} \mathrm{~S}_{2} \mathrm{O}_{8}$ $5 \mathrm{~mL}$ 를 섞어 암실에서 12-16시간 방치 시킨 후 $732 \mathrm{~nm}$ 에서 대조구의 흡광도 값이 $0.7 \pm 0.02$ 가 되도록 메탄올로 희석한 $\mathrm{ABTS}^{+}$용액을 사용하였다. 각각의 추출물 $0.1 \mathrm{~mL}$ 와 $\mathrm{ABTS}^{*}$ 용액 $0.9 \mathrm{~mL}$ 를 첨가하여 혼합한 후 정확히 3 분 후 $732 \mathrm{~nm}$ 에서 흡광도를 측정하였다. 음성대조구 실험은 시료 추출물 대신 메탄올 $0.1 \mathrm{~mL}$ 를 취하여 실험하였으며, 실험구와 음성 대조구의 흡광도를 구하여 백분율(\%)로 나 타내었다.

\section{FRAP 환원력}

FRAP 측정은 Hwang 등(11)의 방법을 참고하여 수행하 였다. Acetate buffer(30 mM, pH 3.6), TPTZ 시약 $(10 \mathrm{mM}$ in $40 \mathrm{mM} \mathrm{HCl})$, 및 $\mathrm{FeCl}_{3}$ 용액 $(20 \mathrm{mM}$ in distilled water $)$ 을 $10: 1: 1(\mathrm{v} / \mathrm{v} / \mathrm{v})$ 의 비율로 혼합하여 FRAP 측정 시약을 조제 하였다. 이 후 항온기 $\left(37^{\circ} \mathrm{C}\right)$ 에서 15 분간 예비반응 후 추출물 $50 \mu \mathrm{L}$ 와 FRAP 시약 $950 \mu \mathrm{L}$ 를 시험관에 분주하고 15 분 반응시켜 $593 \mathrm{~nm}$ 에서 흡광도를 측정하였다. 음성대조구 실험은 추출물 대신 메탄올을 사용하였다.

\section{통계처리}

실험 결과는 SPSS 12.0 package를 사용하여 분산 분석을 수행하였으며 평균 \pm 표준편차로 나타내었다. 각 시료의 분 석 결과에 대한 유의성 검정은 분산 분석을 한 후 $\mathrm{p}<0.05$ 수준에서 Duncan's multiple range test를 실시하였다. 각 실 험은 3회 반복하여 평균값으로 나타내었다.

\section{결과 및 고찰}

\section{유색 소립콩의 두유 발효 과정 중 이화학적 특성 변화}

유색 소립콩의 두유 발효 과정 중 $\mathrm{pH}$, 총산, 생균수 및 $\beta$-glucosidase 효소활성 변화는 Table 1과 같았다. 발효 전 평균 $\mathrm{pH}$ 는 6.28 범위였으며 발효 과정 중 점차적으로 감소 하여 3.96-4.12 범위를 나타냈으며, 발효 60시간째 평균 4.03 으로 감소하였다. 총산은 $\mathrm{pH}$ 감소에 따라 비례적으로 증가 하였으며, 최종 $1.08 \%$ 로 풍산나물콩 발효두유에서 가장 높은 수치를 나타내었고 생균수는 대부분 36-48시간까지 증가하다 60시간째 감소하였으나 콩 품종에 따른 큰 유의 적 차이는 없었다. $\beta$-Glucosidase 활성 측정 결과 모든 유색 소립콩 두유는 발효 전 0.01-0.05 U/mL로 효소활성이 나타 나지 않았다. 그러나 발효 12시간째부터는 효소활성을 조 금씩 나타났으며 발효 과정 중 서서히 증가하는 경향을 나타내었다. 발효 60 시간째에는 $1.69 \mathrm{U} / \mathrm{mL}$ 로 풍산나물콩 발효두유가 가장 높은 효소활성을 나타내었고 이를 이어녹
채콩 발효두유가 $1.60 \mathrm{U} / \mathrm{mL}$ 의 효소활성을 나타내었고 갈 채콩 발효두유 $(1.52 \mathrm{U} / \mathrm{mL})$ 와 다원콩 발효두유 $(1.48 \mathrm{U} / \mathrm{mL})$ 순으로 $\beta$-glucosidase 활성을 나타내었다.

$\mathrm{pH}$ 감소는 젖산균이 생성한 젖산에 기인 한 결과로 젖산 발효 중 $\mathrm{pH}$ 감소 및 총산의 증가 현상은 이미 일반적으로 많이 알려져 있다 $(16,17)$. 한편 발효 60시간째 생균수는 약 간 감소하는 경향을 나타내었으며 이는 미생물 증식곡선 중 사멸기에 들어선 것으로 추측하였으며 미생물 종류에 따라 그 차이는 있으나 이 결과 역시 이미 보고된 연구와 유사하였다(18). 한편 $\beta$-glucosidase는 $\beta$-D-glucopyranoside 결합에 대해 특이성을 보이는 가수분해 효소로 최적 반응 $\mathrm{pH}$ 범위는 3-7로 알려져 있다. 특히 최근 Hwang 등(12)의 콩 품종별 발효두유 연구에서는 유산균의 $\beta$-glucosidase 활 성에 대해 보고하였고 효소활성의 범위는 본 연구와도 유사 하였다. 부가적으로 발효 과정 중 유산균이 생성하는 $\beta$ -glucosidase는 최적의 효소반응 환경에서 phytochmical 계 열의 항산화 성분을 증가시킨다는 연구 결과들이 보고되었 다(19,20).

\section{유색 소립콩의 두유 발효 과정 중 total phenolics 함 량 변화}

Total phenolics 함량은 발효 과정 중 서서히 증가하는 경향을 나타내었다(Fig. 2). Total phenolics 함량은 풍산나물 콩 < 녹채콩 < 갈채콩 < 다원콩 순으로 가장 높았으며, 다원콩은 발효 전 $2.92 \mathrm{mg} / \mathrm{g}$ 에서 발효 60 시간째 $3.03 \mathrm{mg} / \mathrm{g}$ 로 서서히 증가하였다. 갈채콩 역시 비교적 높은 함량을 나타내었고 발효 60 시간째에는 $2.99 \mathrm{mg} / \mathrm{g}$ 으로 다원 콩에는 약간 못 미치는 수준이었다. 한편 가장 낮은 함량을 나타낸 풍산나물콩은 발효 60 시간째 다원콩과 비교하였을 시 약

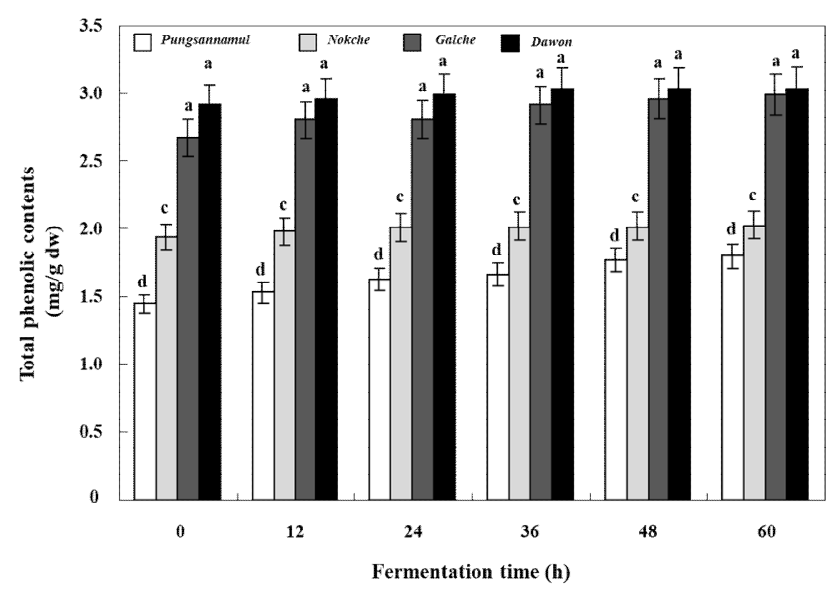

Fig. 2. Change of total phenolic contents during the lactic acid fermentation of soy powder milk with colored small soybean by the potential probiotic Lactobacillus plantarum P1201.

Data represented mean \pm SD of three replicates. All values within a column with different superscript letters are significantly different from each other at $p<0.05$ by Duncan's multiple range test. 
Table 1. Changes of $\mathrm{pH}$, acidity, viable cell number during the lactic acid fermentation of soy powder milk with colored small soybean by the potential probiotic Lactobacillus plantarum P1201

\begin{tabular}{|c|c|c|c|c|c|}
\hline \multirow{2}{*}{$\begin{array}{l}\text { Soybean } \\
\text { cultivars }\end{array}$} & \multirow{2}{*}{$\begin{array}{l}\text { Fermentation } \\
\text { time (h) }\end{array}$} & \multicolumn{4}{|c|}{ Contents } \\
\hline & & $\mathrm{pH}$ & Acidity (\%, as lactic acid) & $\begin{array}{l}\text { Viable cell numbers } \\
(\log \mathrm{CFU} / \mathrm{mL})\end{array}$ & $\begin{array}{c}\beta \text {-Glucosidase activity } \\
(\mathrm{U} / \mathrm{mL})\end{array}$ \\
\hline \multirow{6}{*}{$\begin{array}{l}\text { Pungsannamul } \\
\text { (yellow) }\end{array}$} & 0 & $6.30 \pm 0.25^{1) a 2)}$ & $0.14 \pm 0.01^{\mathrm{d}}$ & $6.78 \pm 0.41^{\mathrm{c}}$ & $0.04 \pm 0.00^{f}$ \\
\hline & 12 & $6.23 \pm 0.25^{\mathrm{a}}$ & $0.18 \pm 0.01^{\mathrm{cd}}$ & $7.00 \pm 0.42^{\mathrm{c}}$ & $0.85 \pm 0.05^{\mathrm{d}}$ \\
\hline & 24 & $4.77 \pm 0.19^{c}$ & $0.70 \pm 0.04^{\mathrm{ab}}$ & $9.46 \pm 0.57^{\mathrm{ab}}$ & $0.97 \pm 0.06^{\mathrm{d}}$ \\
\hline & 36 & $4.42 \pm 0.18^{c}$ & $0.85 \pm 0.05^{\mathrm{ab}}$ & $11.85 \pm 0.71^{\mathrm{a}}$ & $1.26 \pm 0.08^{\mathrm{bc}}$ \\
\hline & 48 & $4.16 \pm 0.17^{\mathrm{cd}}$ & $0.90 \pm 0.05^{\mathrm{a}}$ & $11.88 \pm 0.71^{\mathrm{a}}$ & $1.33 \pm 0.08^{b}$ \\
\hline & 60 & $3.96 \pm 0.16^{\mathrm{d}}$ & $1.08 \pm 0.06^{\mathrm{a}}$ & $11.50 \pm 0.69^{\mathrm{a}}$ & $1.48 \pm 0.09^{\mathrm{ab}}$ \\
\hline \multirow{6}{*}{$\begin{array}{l}\text { Nokchea } \\
\text { (green) }\end{array}$} & 0 & $6.35 \pm 0.25^{\mathrm{a}}$ & $0.14 \pm 0.01^{\mathrm{d}}$ & $6.60 \pm 0.40^{c}$ & $0.01 \pm 0.00^{f}$ \\
\hline & 12 & $6.30 \pm 0.25^{\mathrm{a}}$ & $0.16 \pm 0.01^{\mathrm{cd}}$ & $7.48 \pm 0.45^{\mathrm{bc}}$ & $0.32 \pm 0.02^{\mathrm{e}}$ \\
\hline & 24 & $6.26 \pm 0.25^{\mathrm{a}}$ & $0.20 \pm 0.01^{\mathrm{c}}$ & $8.69 \pm 0.52^{\mathrm{ab}}$ & $0.52 \pm 0.03^{\mathrm{de}}$ \\
\hline & 36 & $4.48 \pm 0.18^{c}$ & $0.74 \pm 0.04^{\mathrm{ab}}$ & $10.98 \pm 0.66^{\mathrm{a}}$ & $1.14 \pm 0.07^{\mathrm{c}}$ \\
\hline & 48 & $4.05 \pm 0.16^{\mathrm{d}}$ & $1.01 \pm 0.06^{\mathrm{a}}$ & $11.93 \pm 0.72^{\mathrm{a}}$ & $1.32 \pm 0.08^{b}$ \\
\hline & 60 & $4.00 \pm 0.16^{d}$ & $1.04 \pm 0.06^{\mathrm{a}}$ & $11.35 \pm 0.68^{\mathrm{a}}$ & $1.60 \pm 0.10^{\mathrm{a}}$ \\
\hline \multirow{6}{*}{$\begin{array}{l}\text { Galchea } \\
\text { (brown) }\end{array}$} & 0 & $6.25 \pm 0.25^{\mathrm{a}}$ & $0.22 \pm 0.01^{\mathrm{c}}$ & $7.00 \pm 0.42^{\mathrm{c}}$ & $0.05 \pm 0.00^{f}$ \\
\hline & 12 & $6.23 \pm 0.25^{\mathrm{a}}$ & $0.22 \pm 0.01^{\mathrm{c}}$ & $7.00 \pm 0.42^{\mathrm{c}}$ & $0.71 \pm 0.04^{\mathrm{d}}$ \\
\hline & 24 & $6.15 \pm 0.25^{\mathrm{a}}$ & $0.23 \pm 0.01^{\mathrm{c}}$ & $8.26 \pm 0.50^{\mathrm{ab}}$ & $0.82 \pm 0.05^{\mathrm{d}}$ \\
\hline & 36 & $4.18 \pm 0.17^{\mathrm{cd}}$ & $0.72 \pm 0.04^{\mathrm{ab}}$ & $10.77 \pm 0.65^{\mathrm{a}}$ & $1.23 \pm 0.07^{\mathrm{bc}}$ \\
\hline & 48 & $4.18 \pm 0.17^{\mathrm{cd}}$ & $0.88 \pm 0.05^{\mathrm{a}}$ & $11.89 \pm 0.71^{\mathrm{a}}$ & $1.47 \pm 0.09^{\mathrm{ab}}$ \\
\hline & 60 & $4.12 \pm 0.16^{\mathrm{cd}}$ & $0.90 \pm 0.06^{\mathrm{a}}$ & $11.92 \pm 0.72^{\mathrm{a}}$ & $1.52 \pm 0.09^{\mathrm{a}}$ \\
\hline \multirow{6}{*}{$\begin{array}{l}\text { Dawon } \\
\text { (black) }\end{array}$} & 0 & $6.22 \pm 0.25^{a}$ & $0.18 \pm 0.01^{\text {cd }}$ & $7.43 \pm 0.45^{\mathrm{bc}}$ & $0.03 \pm 0.00^{\mathrm{f}}$ \\
\hline & 12 & $6.10 \pm 0.24^{\mathrm{a}}$ & $0.18 \pm 0.01^{\mathrm{cd}}$ & $7.90 \pm 0.47^{b}$ & $0.26 \pm 0.02^{\mathrm{e}}$ \\
\hline & 24 & $5.52 \pm 0.22^{b}$ & $0.52 \pm 0.03^{b}$ & $10.41 \pm 0.62^{\mathrm{ab}}$ & $0.49 \pm 0.03^{\text {de }}$ \\
\hline & 36 & $4.44 \pm 0.18^{\mathrm{c}}$ & $0.70 \pm 0.04^{\mathrm{ab}}$ & $11.93 \pm 0.72^{\mathrm{a}}$ & $1.12 \pm 0.07^{\mathrm{c}}$ \\
\hline & 48 & $4.30 \pm 0.17^{\mathrm{c}}$ & $0.85 \pm 0.05^{\mathrm{ab}}$ & $11.98 \pm 0.72^{\mathrm{a}}$ & $1.35 \pm 0.08^{b}$ \\
\hline & 60 & $4.02 \pm 0.16^{\mathrm{d}}$ & $1.03 \pm 0.06^{\mathrm{a}}$ & $11.93 \pm 0.72^{\mathrm{a}}$ & $1.69 \pm 0.10^{\mathrm{a}}$ \\
\hline
\end{tabular}

\footnotetext{
${ }^{1)}$ Data represented mean \pm SD of three replicates
}

${ }^{2)}$ All values within a column with different superscript letters are significantly different from each other at $p<0.05$ by Duncan's multiple range test

1.7 배의 함량 차이가 있는 것으로 나타났다. 이러한 결과는 검정콩에 함유된 anthocyanin 함량에 기인한 것으로 사료되 었다.

활성산소종(reactive oxygen species)은 보통 인체의 호흡 과정에서 몸 속으로 들어간 산소가 산화과정과 대사과정을 반복적으로 거쳐 생성되며 과잉 생성 시 세포를 손상시키는 산화력이 강한 산소로 정의된다. 한편 super oxide, hydrogen peroxide, hydroxyl과 같은 free radical은 노화의 주요 원인으 로 이러한 문제를 예방하기 위해 과거부터 오늘날까지 항산 화 효능이 우수한 polyphenol에 대한 연구가 활발히 이루어 졌다 $(5,21,22)$. 특히 생리활성 물질 중 anthocyanin은 꽃이나 과실 등에 포함되어 있는 색소 배당체로서 검정콩에 상당량 함유되어 있다(23). 또한 주요 성분인 cyanidin-3-glucoside $(\mathrm{C} 3 \mathrm{G})$ 및 delphinidin-3-glucoside(D3G)가 우수한 활성을 나
타낸다고 Lee 등(21)과 $\mathrm{Kim}$ 등(24)이 보고하였다. Kong 등(25)도 anthocyanin 함량에 따라 생리활성이 우수하다 보 고하였고 이와 유사한 연구 결과들이 보고되어 있다(24). 따라서 이러한 결과를 종합적으로 볼 때 본 연구 또한 검정 콩 혹은 유색콩에 함유된 anthocyanin 혹은 pro-anthocyanin 화합물에 기인한 것으로 추측되며 유색콩 껍질의 anthocyanin 혹은 pro-anthocyanin 함량에 따라 항산화 활성 차이가 나타난 것으로 사료된다.

\section{유색 소립콩의 두유 발효 과정 중 isoflavone 함량 변화}

Isoflavone 함량 변화를 분석한 결과 Table 3과 Figs. 3-4에 나타낸바와 같았다. 일반적으로 콩의 isoflavone은 12 가지 화합물로써 4 개의 그룹으로 구분되며 본 연구에서는 총 9종류의 배당체(daidzin, glycitin, genistin, malonyl-daidzin, 
Table 2. Changes of isoflavone contents during the lactic acid fermentation of soy powder milk with colored small soybean by the potential probiotic Lactobacillus plantarum P1201

\begin{tabular}{|c|c|c|c|c|c|c|c|c|c|c|c|c|c|c|}
\hline \multirow{3}{*}{ Cultivars } & \multirow{3}{*}{$\begin{array}{l}\text { Fermentation } \\
\text { time (h) }\end{array}$} & \multicolumn{13}{|c|}{ Isoflavone contents $(\mathrm{\mu g} / \mathrm{g})$} \\
\hline & & \multicolumn{3}{|c|}{ Glycosidesb } & \multicolumn{3}{|c|}{ Malonylglycosides } & \multicolumn{3}{|c|}{ Acetylglycosides } & \multicolumn{3}{|c|}{ Aglycones } & \multirow{2}{*}{ Totals } \\
\hline & & Daickin & Glycitin & Genistin & idżn & ycitin & Genistin & Daidzin & Glycitin & Genistin & Daidzein & Glycitein & Genistein & \\
\hline \multirow{6}{*}{$\begin{array}{l}\text { Pungsan } \\
\text { namul } \\
\text { (yellow) }\end{array}$} & 0 & $183.73 \pm 7.35^{1 / 22)}$ & $133.15+5.33^{\mathrm{a}}$ & $220.43 \pm 8.82^{\mathrm{a}}$ & $32.24 \pm 1.29^{9}$ & $21.35 \pm 0.85^{\mathrm{a}}$ & $36.50 \pm 2.19^{b}$ & $0.80 \pm 0.03^{\mathrm{a}}$ & $3.99 \pm 0.16^{a}$ & $2.00 \pm 0.08^{\mathrm{a}}$ & $31.73 \pm 1.27^{\mathrm{d}}$ & $12.39 \pm 0.50^{\circ}$ & $24.00 \pm 1.44^{b}$ & $702.31 \pm 35.12^{\mathrm{a}}$ \\
\hline & 12 & $176.70 \pm 8.84^{a}$ & $124.50 \pm 6.23 \mathrm{a}$ & $211.96 \pm 10.61^{\mathrm{a}}$ & $29.13 \pm 1.17^{\mathrm{a}}$ & $19.56 \pm 0.98^{\mathrm{a}}$ & $33.80 \pm 1.35^{b}$ & $\left.t^{3}\right)^{3}$ & $1.47 \pm 0.07^{\circ}$ & $0.74 \pm 0.04^{d}$ & $29.02 \pm 1.45^{\mathrm{d}}$ & $11.11 \pm 0.56^{c}$ & $23.00 \pm 0.92^{b}$ & $660.98 \pm 33.05^{\mathrm{a}}$ \\
\hline & 24 & $146.74 \pm 8.80^{b}$ & $119.71 \pm 7.1^{\mathrm{ab}}$ & $196.66 \pm 1180^{\mathrm{ab}}$ & $26.80 \pm 1.10^{\mathrm{ab}}$ & $17.94 \pm 1.08^{\mathrm{a}}$ & $30.98 \pm 1.55^{b}$ & tr & $2.86 \pm 0.17^{b}$ & $1.43 \pm 0.09^{b}$ & $44.19 \pm 2.65^{c}$ & $11.43 \pm 0.46^{c}$ & $28.01 \pm 1.40^{b}$ & $626.75 \pm 31.34^{\mathrm{ab}}$ \\
\hline & 36 & $109.92 \pm 4.40^{c}$ & $123.19 \pm 4.93 \mathrm{a}$ & $178.94+7.16^{b}$ & $22.97 \pm 1.15^{\mathrm{ab}}$ & $15.07 \pm 0.90^{\mathrm{ab}}$ & $28.57 \pm 1.11^{b}$ & tr & $2.14 \pm 0.09^{b}$ & $1.07 \pm 0.04^{c}$ & $71.47 \pm 2.86^{\mathrm{a}}$ & $11.05 \pm 0.66^{\circ}$ & $41.56 \pm 1.66^{\mathrm{a}}$ & $605.96 \pm 30.30^{\mathrm{ab}}$ \\
\hline & 48 & $103.45 \pm 5.17^{c}$ & $123.45 \pm 6.17 \mathrm{a}$ & $174.40 \pm 8.72^{b}$ & $23.27 \pm 1.16^{\mathrm{ab}}$ & $16.96 \pm 0.68^{\mathrm{ab}}$ & $25.35 \pm 1.27^{b}$ & tr & $1.96 \pm 0.1^{b}$ & $0.98 \pm 0.05^{\circ}$ & $74.35 \pm 3.72^{\mathrm{a}}$ & $10.97 \pm 0.44^{c}$ & $43.52 \pm 2.61^{\mathrm{a}}$ & $598.65 \pm 29.93^{2 \mathrm{~b}}$ \\
\hline & 60 & $84.58 \pm 5.07^{\mathrm{d}}$ & $126.10 \pm 7.57^{\mathrm{a}}$ & $159.93 \pm 9.60^{\text {bc }}$ & $24.00 \pm 1.20^{\mathrm{ab}}$ & $17.43 \pm 0.87^{\mathrm{a}}$ & $25.67 \pm 1.54^{b}$ & tr & $1.72 \pm 0.8^{b c}$ & $0.86 \pm 0.05^{\text {cd }}$ & $87.37 \pm 5.24^{a}$ & $12.38 \pm 0.62^{c}$ & $51.29 \pm 2.05^{\mathrm{a}}$ & $591.34 \pm 29.57^{7 \mathrm{~b}}$ \\
\hline \multirow{6}{*}{$\begin{array}{l}\text { Nokchea } \\
\text { (green) }\end{array}$} & 0 & $173.83 \pm 8.69^{a}$ & $98.87 \pm 4.94^{\mathrm{bc}}$ & $143.05 \pm 7.15^{c}$ & $23.72 \pm 1.19^{\mathrm{ab}}$ & $16.16 \pm 0.81^{a b}$ & $28.06 \pm 1.40^{b}$ & $\mathrm{ND}^{4}$ & $3.12 \pm 0.16^{b}$ & $1.56 \pm 0.08^{b}$ & $82^{e}$ & $5.99 \pm 0.30^{\mathrm{d}}$ & $6.68 \pm 0.33^{d}$ & $517.38 \pm 25.87^{b}$ \\
\hline & 12 & $167.07 \pm 8.35^{\mathrm{a}}$ & $95.04 \pm 4.75^{b c}$ & $135.96 \pm 6.80^{c}$ & $22.34 \pm 1.12^{\mathrm{ab}}$ & $15.31 \pm 0.77^{\mathrm{ab}}$ & $26.31 \pm 1.32^{b}$ & $\mathrm{ND}$ & $2.94 \pm 0.15^{b}$ & $1.47 \pm 0.07^{\mathrm{b}}$ & $15.99 \pm 0.80^{\circ}$ & $5.95 \pm 0.30^{\mathrm{d}}$ & $6.53 \pm 0.33^{\mathrm{d}}$ & $494.90 \pm 24.75^{b}$ \\
\hline & 24 & $172.02 \pm 8.60^{a}$ & $98.12 \pm 4.91^{\mathrm{cc}}$ & $140.29 \pm 7.01^{c}$ & $23.42 \pm 1.17^{\mathrm{ab}}$ & $15.60 \pm 0.78^{\mathrm{ab}}$ & $26.92 \pm 1.35^{b}$ & $\mathrm{ND}$ & $3.04 \pm 0.15^{b}$ & $1.52 \pm 0.08^{b}$ & $16.64 \pm 0.83^{e}$ & $6.25 \pm 0.31^{\mathrm{d}}$ & $6.84 \pm 0.34^{d}$ & $510.66 \pm 25.53^{b}$ \\
\hline & 36 & $108.59 \pm 5.43^{c}$ & $107.46 \pm 5.37^{b}$ & $126.14 \pm 6.31^{\mathrm{d}}$ & $23.80 \pm 1.19^{\mathrm{ab}}$ & $15.97 \pm 0.80^{\mathrm{ab}}$ & $26.69 \pm 1.33^{b}$ & $\mathrm{ND}$ & $2.72 \pm 0.14^{b}$ & $1.36 \pm 0.07^{b}$ & $63.05 \pm 3.15^{b}$ & $6.71 \pm 0.34^{d}$ & $19.42 \pm 0.97^{\mathrm{x}}$ & $501.92 \pm 25.10^{b}$ \\
\hline & 48 & $87.03 \pm 4.35^{\text {cd }}$ & $103.86 \pm 5.19^{b}$ & $112.70 \pm 5.64^{\mathrm{de}}$ & $21.41 \pm 1.07^{b}$ & $14.71 \pm 0.74^{\mathrm{ab}}$ & $23.83 \pm 1.19^{b}$ & $\mathrm{ND}$ & $1.85 \pm 0.00^{b}$ & $\mathrm{ND}$ & $76.84 \pm 3.84^{a}$ & $6.19 \pm 0.31^{\mathrm{d}}$ & $25.16 \pm 1.26^{b}$ & $473.58 \pm 23.68^{\mathrm{bc}}$ \\
\hline & 60 & $94.69 \pm 4.73^{c}$ & $99.15 \pm 4.96^{a}$ & $112.23 \pm 5.61^{\mathrm{de}}$ & $22.71 \pm 1.14^{b}$ & $14.82 \pm 0.74^{\mathrm{ab}}$ & $24.71 \pm 1.24^{b}$ & $\mathrm{ND}$ & $1.42 \pm 0.07^{\circ}$ & $\mathrm{ND}$ & $66.26 \pm 3.31^{b}$ & $5.72 \pm 0.22^{\mathrm{d}}$ & $21.64 \pm 1.08^{\mathrm{a}}$ & $463.35 \pm 23.17^{\mathrm{bc}}$ \\
\hline \multirow{6}{*}{$\begin{array}{l}\text { Galchea } \\
\text { (brown) }\end{array}$} & 0 & $86.79 \pm 3.47^{\text {dd }}$ & $105.72 \pm 4.23^{b}$ & $163.87 \pm 6.55^{\mathrm{bc}}$ & $15 ., 2 L-0 . J 0$ & $13.93 \pm 0.56^{6}$ & $37.56 \pm 1.50^{b}$ & 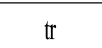 & $1.56 \pm 0.06^{\mathrm{bc}}$ & 10 & $5.33 \pm 0.21^{\mathrm{f}}$ & $25.20 \pm 1.01^{b}$ & Y.1D-0.J1 & $463.01 \pm 18.52^{b c}$ \\
\hline & 12 & $85.45 \pm 3.42^{\text {ed }}$ & $101.74 \pm 4.07^{b}$ & $163.43 \pm 6.54^{\text {bc }}$ & $13.23 \pm 0.53^{c}$ & $13.12 \pm 0.52^{\mathrm{b}}$ & $36.97 \pm 1.48^{b}$ & tr & $1.39 \pm 0.06^{c}$ & $\mathrm{ND}$ & $5.23 \pm 0.21^{f}$ & $25.78 \pm 1.03^{b}$ & $9.31 \pm 0.37^{\circ}$ & $455.65 \pm 18.23^{\text {bc }}$ \\
\hline & 24 & $79.04 \pm 3.16^{d}$ & $86.81 \pm 3.47^{\circ}$ & $127.58 \pm 5.10^{d}$ & $33.28 \pm 1.33^{a}$ & $23.05 \pm 0.92^{a}$ & $86.72 \pm 3.47^{a}$ & tr & $1.92 \pm 0.08^{b}$ & $\mathrm{ND}$ & $3.41 \pm 0.14^{\mathrm{f}}$ & $28.20 \pm 1.13^{b}$ & $8.50 \pm 0.34^{c}$ & $478.51 \pm 19.14^{\text {bc }}$ \\
\hline & 36 & $50.47 \pm 2.02^{e}$ & $122.85 \pm 4.91^{\mathrm{a}}$ & $116.40 \pm 4.66^{\mathrm{de}}$ & $12.02 \pm 0.48^{c}$ & $12.12 \pm 0.48^{b}$ & $32.25 \pm 1.29^{b}$ & tr & $0.87 \pm 0.03^{\mathrm{d}}$ & $\mathrm{ND}$ & $27.89 \pm 1.12^{\mathrm{d}}$ & $26.25 \pm 1.05^{\mathrm{b}}$ & $27.07 \pm 1.08^{b}$ & $428.19 \pm 17.13^{c}$ \\
\hline & 48 & $48.70 \pm 1.95^{e}$ & $121.25 \pm 4.85^{\mathrm{a}}$ & $115.87 \pm 4.63^{\mathrm{de}}$ & $11.23 \pm 0.45^{c}$ & $12.45 \pm 0.50^{b}$ & $31.24 \pm 1.25^{b}$ & tr & $0.90 \pm 0.04^{d}$ & $\mathrm{ND}$ & $29.54 \pm 1.18^{d}$ & $25.52 \pm 1.02^{b}$ & $28.30 \pm 1.13^{b}$ & $424.98 \pm 17.00^{c}$ \\
\hline & 60 & $47.65 \pm 1.91^{e}$ & $124.53 \pm 4.98^{\mathrm{a}}$ & $111.40 \pm 4.46^{\mathrm{de}}$ & $11.61 \pm 0.46^{c}$ & $12.01 \pm 0.48^{b}$ & $30.58 \pm 1.22^{b}$ & 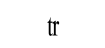 & $0.69 \pm 0.03^{e}$ & $\mathrm{ND}$ & $30.36 \pm 1.21^{\mathrm{d}}$ & $27.00 \pm 1.08^{b}$ & $29.11 \pm 1.16^{b}$ & $424.95 \pm 17.00^{\circ}$ \\
\hline \multirow{6}{*}{$\begin{array}{l}\text { Dawon } \\
\text { (black) }\end{array}$} & 0 & $92.77 \pm 4.64^{c}$ & $96.50 \pm 4.81^{\mathrm{cc}}$ & $134.56 \pm 8.07^{\circ}$ & $19.33 \pm 1.16^{b}$ & $18.10 \pm 1.09^{2}$ & $36.66 \pm 2.20^{b}$ & tr & $1.63 \pm 0.08^{\mathrm{bc}}$ & $\mathrm{ND}$ & $7.14 \pm 0.43^{f}$ & $39.26 \pm 2.36^{\mathrm{a}}$ & $10.13 \pm 0.61^{c}$ & $456.11 \pm 27.37^{\mathrm{bc}}$ \\
\hline & 12 & $97.16 \pm 4.86^{\circ}$ & $100.66 \pm 5.03^{b}$ & $146.71 \pm 8.80^{c}$ & $20.63 \pm 1.24^{b}$ & $19.22 \pm 1.15^{\mathrm{a}}$ & $39.92 \pm 2.40^{b}$ & tr & $1.75 \pm 0.00^{b}$ & $\mathrm{ND}$ & $7.71 \pm 0.46^{f}$ & $43.24 \pm 2.59^{\mathrm{a}}$ & $11.11 \pm 0.67^{\mathrm{c}}$ & $488.12 \pm 29.29^{b}$ \\
\hline & 24 & $92.72 \pm 4.64^{\circ}$ & $97.49 \pm 4.87^{\mathrm{cc}}$ & $141.24 \pm 8.47^{\circ}$ & $19.30 \pm 1.16^{b}$ & $17.85 \pm 1.07^{\mathrm{a}}$ & $35.11 \pm 2.11^{b}$ & tr & $1.51 \pm 0.08^{\mathrm{bc}}$ & $\mathrm{ND}$ & $8.54 \pm 0.51^{\mathrm{f}}$ & $44.24 \pm 2.65^{\mathrm{a}}$ & $11.22 \pm 0.67^{\mathrm{c}}$ & $469.2 \pm 28.15^{\mathrm{bc}}$ \\
\hline & 36 & $56.19 \pm 2.81^{e}$ & $103.17 \pm 5.16^{b}$ & $113.55 \pm 6.81^{\mathrm{de}}$ & $19.39 \pm 1.16^{b}$ & $18.20 \pm 1.09^{9}$ & $33.07 \pm 1.98^{b}$ & tr & $0.98 \pm 0.05^{\mathrm{d}}$ & $\mathrm{ND}$ & $30.47 \pm 1.83^{\mathrm{d}}$ & $38.47 \pm 2.31^{\mathrm{a}}$ & $27.62 \pm 1.66^{b}$ & $441.10 \pm 26.47^{\mathrm{bc}}$ \\
\hline & 48 & $58.18 \pm 2.91^{\mathrm{e}}$ & $102.11 \pm 5.11^{\mathrm{b}}$ & $115.20 \pm 6.91^{\mathrm{de}}$ & $18.44 \pm 1.11^{b}$ & $18.10 \pm 1.09^{9}$ & $32.58 \pm 1.95^{b}$ & tr & $0.90 \pm 0.05^{d}$ & ND & $29.24 \pm 1.75^{\mathrm{d}}$ & $37.75 \pm 2.27^{a}$ & $26.04 \pm 1.56^{b}$ & $438.53 \pm 26.31^{\mathrm{bc}}$ \\
\hline & 60 & $48.04 \pm 2.40^{\circ}$ & $100.77 \pm 5.04^{b}$ & $100.18 \pm 6.01^{e}$ & $17.62 \pm 1.06^{b}$ & $18.36 \pm 1.10^{a}$ & $31.30 \pm 1.88^{b}$ & tr & $0.72 \pm 0.04^{e}$ & $\mathrm{ND}$ & $33.55 \pm 2.01^{d}$ & $33.97 \pm 2.04^{a}$ & $30.13 \pm 1.81^{b}$ & $414.63 \pm 24.88^{c}$ \\
\hline
\end{tabular}

\footnotetext{
${ }^{11}$ All values are means of determinations in three independent experiment. Data represented mean \pm SD of three replicates.

${ }^{2)}$ All values within a column with different superscript letters are significantly different from each other at $p<0.05$ by Duncan's multiple range test.

$\left.{ }^{3}\right) \mathrm{tr}$, trace $(<0.002 \mu \mathrm{g} / \mathrm{g})$.

${ }^{4} \mathrm{ND}$, not detected.
}

malonyl-glycitin, malonyl-genistin, acetyl-daidzin, acetylglycitin, 및 acetyl-genistin) 및 3종류의 비배당체(daidzein, glycitein, 및 genistein)가 검출되었다(Fig. 3A-H). 그러나 녹 채콩에서는 peak 6번 acetyl-daidzin이 검출되지 않았고(Fig. 3C) 발효 60시간째에는 peak 11번인 acetyl-genistin이 검출 되지 않았다(Fig. 3D). 또한 갈채콩 및 다원콩에서는 peak 11번 acetyl-genistin이 공통적으로 검출되지 않았다(Fig. 3E-H). 전체적인 HPLC 크로마토그램 변화는 발효가 진행 됨에 따라 glycosides(peak 1-3) 형태가 줄어들고 비배당체 isoflavone(peak 9,12) 형태가 증가하였으며, acetyl-glycosides 및 malonyl-glycosides(peak 4-8,11) 형태는 발효가 진행되는 동안 큰 변화가 없는 것으로 나타났다(Fig. $3 \mathrm{~A}-\mathrm{H})$. 비배당체 isoflavone(daidzein, glycitein, 및 genistein) 함량은 발효 60 시간 후 풍산나물콩에서 $151.04 \mathrm{\mu g} / \mathrm{g}$ 이 검출되었고, 녹채콩 $-93.62 \mu \mathrm{g} / \mathrm{g}$, 갈채콩-86.47 $\mathrm{\mu g} / \mathrm{g}$, 및 다원-97.67 $\mu \mathrm{g} / \mathrm{g}$ 이 검출되 었다(Table 3). 한편 다원콩은 발효 전 glycosides 형태 비율 이 $80.36 \%$ 였으나 발효 60 시간째 $66.06 \%$ 로 감소하였고 이 에 상응하여 $5.61 \%$ 의 비배당체 isoflavone 형태는 발효 60 시 간째 $23.55 \%$ 를 나타내었으며 풍산나물콩(25.54\%)과는 유 의적 차이는 없었다(Fig. 4A-D). 그 외 발효 60시간째 비배 당체 isoflavone 비율로는 녹채콩-20.20\%(Fig. 4B) 및 갈채 콩 두유에서 20.35\%(Fig. 4C)를 나타내었다.

두류 식품에서의 배당체 및 비배당체의 가장 큰 변화 요인은 발효미생물이 가지는 $\beta$-glucosidase 활성에 의한 것 

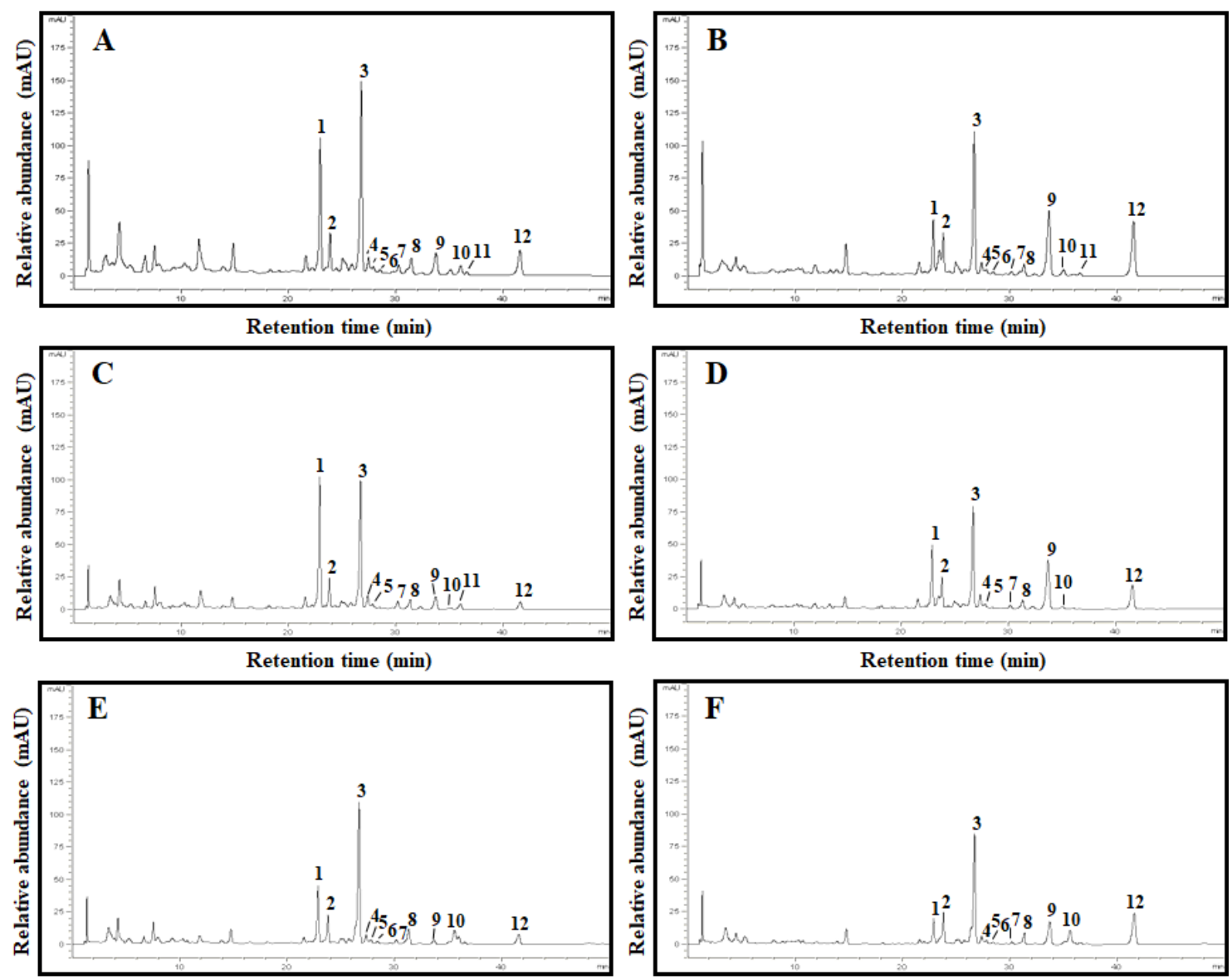

Retention time (min)

Retention time (min)

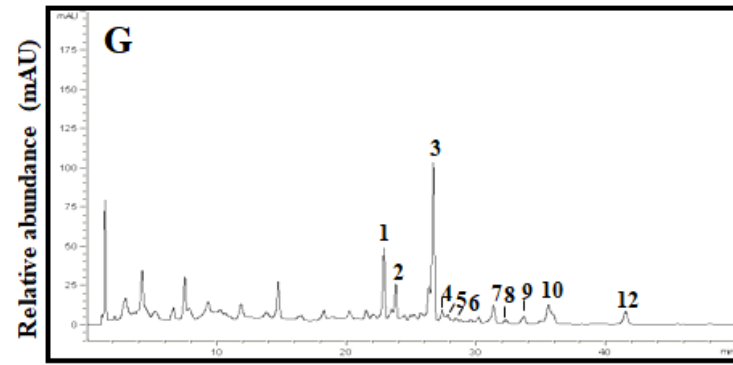

Retention time (min)

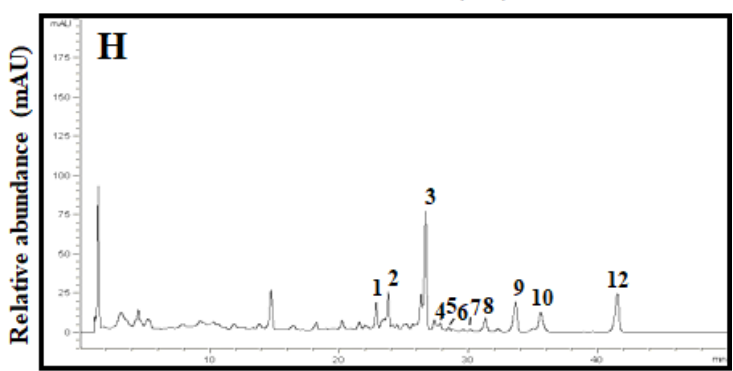

Retention time (min)

Fig. 3. HPLC chromatograms of isoflavones in SPM $(0 \mathrm{~h})$ and fermented SPM $(60 \mathrm{~h})$ extracts.

A, isoflavones in SPM $(0 \mathrm{~h})$ extract of Pungsannamul, B, isoflavones in fermented SPM $(60 \mathrm{~h})$ extract of Pungsannamul, C, isoflavones in SPM $(0 \mathrm{~h})$ extract of Nokche, D, isoflavones in fermented SPM $(60 \mathrm{~h})$ extract of Nokche; E, isoflavones in SPM $(0 \mathrm{~h})$ extract of Galche, F, isoflavones in fermented SPM (60 h) extract of Galche, G, isoflavones in SPM $(0 \mathrm{~h})$ extract of Dawom, $\mathrm{H}$, isoflavones in fermented SPM $(60 \mathrm{~h})$ extract of Dawon.

1, daidzin; 2, glycitin; 3, genistin; 4, malonyldaidzin; 5, malonyglycitin; 6, acetyldaidzin; 7, acetylglycitin; 8, malonylgenistin; 9, daidzein; 10, glycitein; 11, acetylgenistin; 12, genistein.

이라고 보고되어있다(26-28). 본 연구에서는 Marazza 등 (19)과 Rodriguez-Roque 등(29)의 결과와 마찬가지로 발효 가 진행됨에 따라 젖산균이 생성하는 젖산과 $\beta$-glucosidase 활성에 의해 당 결합이 끊어지면서 결과적으로는 9종류 의 배당체 isoflavone 함량이 감소하는 반면, 비배당체 isoflavone 함량이 증가하는 것으로 최종 판단하였다.
유색 소립콩의 두유 발효 과정 중 라디칼 소거활성 및 환 원력 변화

소립콩 두유 발효 과정 중 라디칼 소거활성 및 환원력 변화는 Fig. 5 와 같았다. DPPH 및 $\mathrm{ABTS}$ 라디칼 소거활성은 전체적으로 발효 과정에 따라 증가하였다. DPPH 라디칼 소거활성은 풍산나물콩이 발효 60 시간째 $40.58 \%$ 의 가장 낮은 활성을 나타내었고 다원콩은 $95.25 \%$ 로 가장 우수하였 다(Fig. 5A). ABTS 역시 풍산나물콩이 발효 60시간째 

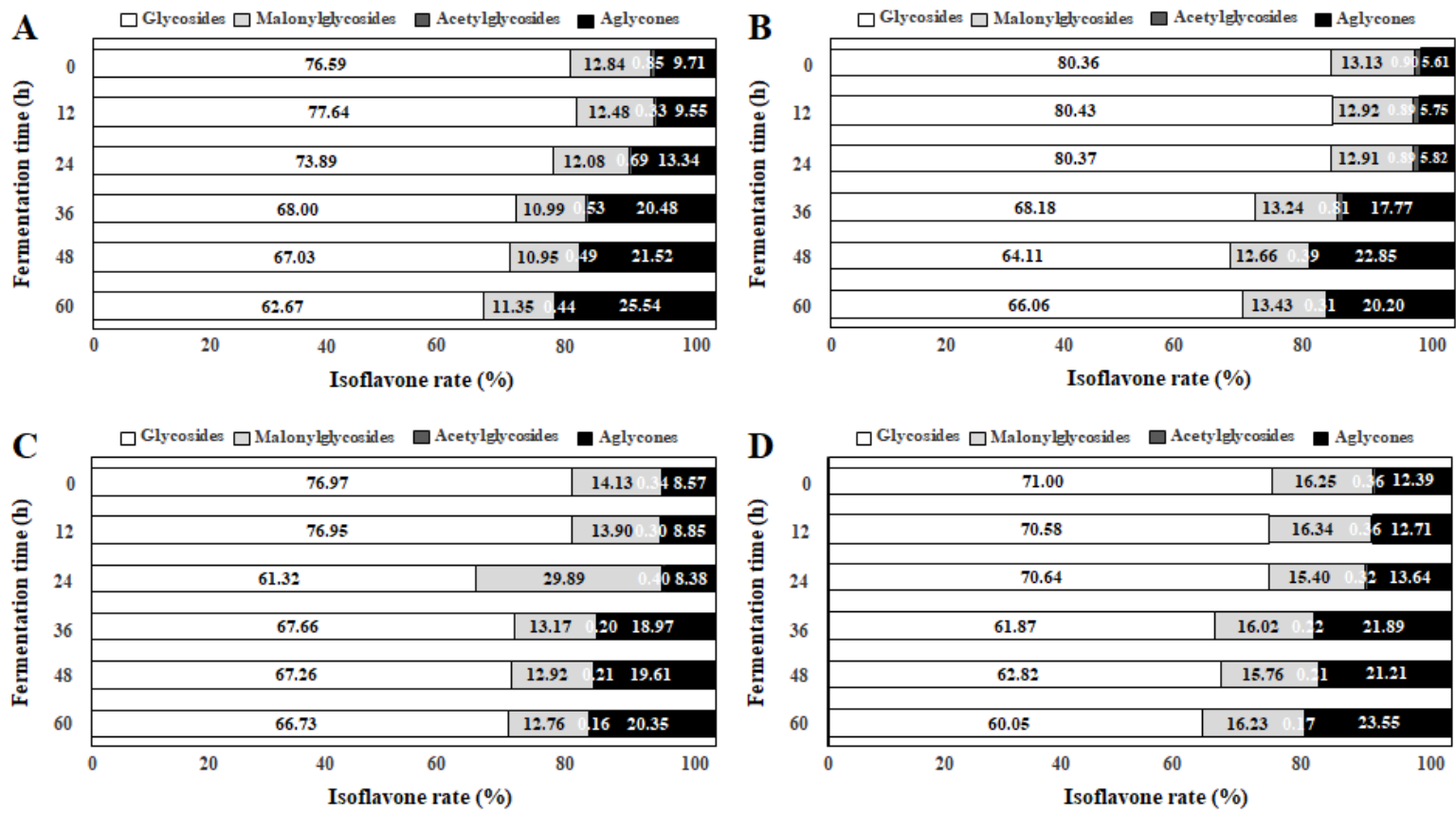

Fig. 4. Change of isoflavone rate during the lactic acid fermentation of soy powder milk with colored small soybean by the potential probiotic Lactobacillus plantarum P1201.

A, Pungsannamul soybean; B, Nokchea soybean; C, Galchea soybean; D, Dawon soybean.

$51.44 \%$, 다원콩 $82.77 \%$ 의 활성을 나타내어 $\mathrm{DPPH}$ 라디칼 소거활성과 완벽히 일치하는 경향을 나타내었다(Fig. 5B). 이러한 라디칼 소거활성 결과와 마찬가지로 FRAP 환원력 역시 발효 과정 중 점차 증가하였고, 발효 60시간째 다원콩 은 1.79 환원력으로 가장 우수하였다(Fig. 5C). 한편 녹채콩 및 갈채콩은 라디칼 활성 및 환원력이 발효 중 증가는 하였 으나 그 활성은 다소 낮은 결과를 나타내었다(Fig. $5 \mathrm{~A}-\mathrm{C}$ ).

DPPH 측정은 a-diphenyl- $\beta$-picrylhydrazyl 라디칼의 소거 능을 이용한 방법으로 현재까지도 가장 광범위하게 항산화 활성 측정에 사용되고 있다(30). ABTS 역시 DPPH와 같은 원리지만 수용성 및 지용성 물질 모두를 측정할 수 있는 특징이 있다(31). Kim 등(24)은 콩 원료에 따른 항산화 활성 차이는 anthocyanin과 같은 색소화합물 함량에 비례한다고 보고하였고, Tsangalis 등(26), Zhao 등(18,28), 및 Hou 등(17) 도 두유의 젖산발효 중 비배당체 isoflavone 함량이 크게 증가한다고 보고하였다. 따라서 본 연구의 우수한 항산화 활성은 발효 중 생성 된 비배당체 isoflavone과 anthocyanin 함량 차이에 그 이유가 있을 것으로 판단되어 향후 anthocyanin에 대한 추가 분석이 필요할 것으로 사료된다. 이로써 L plantarum P1201 유산균을 사용하여 제조한 유색 소립콩 발효두유는 적당한 산미를 형성함과 동시에 비교적 우수한 $\beta$-glucosidase 활성을 나타내며 특히 발효 과정 중 비배당체 isoflavone 및 항산화 활성이 증가하므로 여성 호 르몬 대체재로써 충분한 효과를 가질 수 있을 것으로 사료 된다.

\section{요 약}

본 연구는 잠재적인 생균제제 Lactobacillus plantarum P1201에 의한 유색 소립콩 분말 두유의 젖산발효 중 이화학 적 특성, 총 페놀릭스와 이소플라본 함량 및 항산화 활성 (DPPH와 $\mathrm{ABTS}$ 라디칼 소거활성 및 $\mathrm{FRAP}$ 환원력) 변화를 연구하였다. 콩 분말 두유의 발효 중 $\mathrm{pH}$ 는 감소하였으나, 산도, 생균수 및 $\beta$-glucosidase 활성은 증가하였다. 총 이소 플라본 함량은 풍산나물콩이 다른 유색 소립콩보다 함량이 높았다. 발효과정에서 배당체 이소플라본인 daidzin과 genistin 함량은 감소하였고 이에 상응하여 비배당체 이소 플라본인 daidzein과 genistein 함량은 급격히 증가하였다. 특히, 발효 60 시간 후 발효된 풍산나물콩 분말 두유의 daidzein과 genistein 함량은 $87.37 \mu \mathrm{g} / \mathrm{g}$ and $51.29 \mu \mathrm{g} / \mathrm{g}$ 으로 다른 시료들보다 함량이 가장 높았다. 총 페놀릭스 함량은 다른이 다른 유색 소립콩보다 함량이 높았다. 총 페놀릭스 함량은 색 소립콩 분말 두유의 젖산발효 중 0.44-2.92 $\mathrm{mg} / \mathrm{g}(0 \mathrm{~h})$ 에서 $1.79-3.03 \mathrm{mg} / \mathrm{g}(60 \mathrm{~h})$ 로 급격히 증가하였다. 끝으로, 발효된 콩 분말 두유는 $\mathrm{DPPH}$ 와 $\mathrm{ABTS}$ 라디칼 소거 활성 및 FRAP 환원력은 각각 28.7-40.6에서 90-95.3\%,

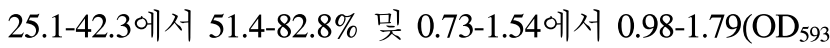
${ }_{n m}$ )로 증가하였다. 발효된 콩 분말 두유는 유색 소립콩의 가치를 증대시킬 수 있다. 

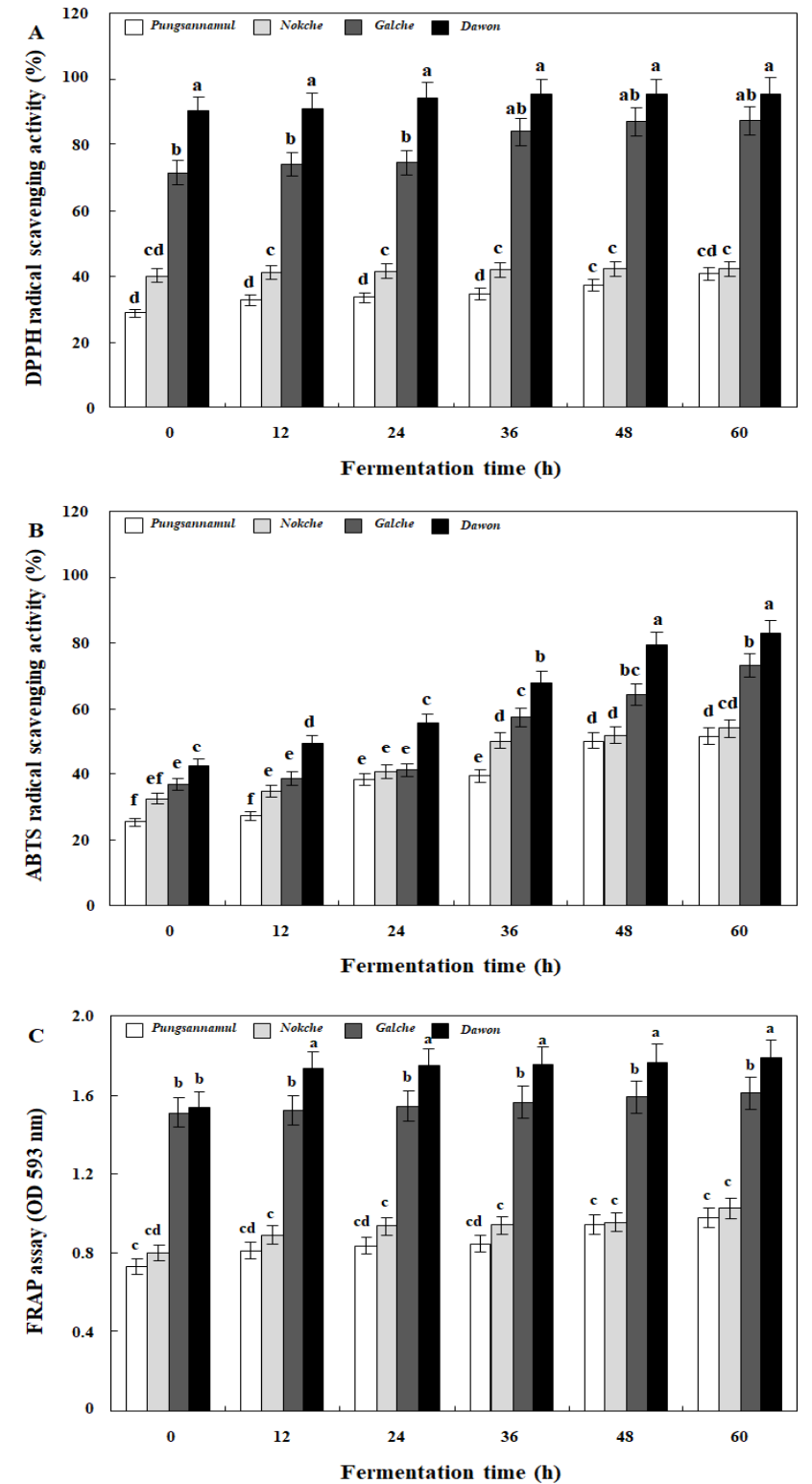

Fig. 5. Change of DPPH (A) and ABTS (B) radical scavenging activities and FRAP assay (C) during the lactic acid fermentation of soy powder milk with colored small soybean by the potential probiotic Lactobacillus plantarum P1201.

Data represented mean \pm SD of three replicates. All values within a column with different superscript letters are significantly different from each other at $p<0.05$ by Duncan's multiple range test.

\section{감사의 글}

이 논문은 2017년 국립경남과학기술대학교의 연구비 지 원에 의하여 연구되었습니다.

\section{References}

1. Yang CS, Landau JM, Huang MT, Newmark HL (2001)
Inhibition of carcinogenesis by dietary polyphenolic compounds. Annu Rev Nutr, 21, 381-406

2. Park SB, Kim JD, Lee NR, Jeong JH, Jeong SY, Lee HS, Hwang DY, Lee JS, Son HJ (2011) Isolation and characteristics of lactic acid bacteria with angiotensinconverting enzyme inhibitory and antioxidative activities. J Life Sci, 21, 1428-1433

3. Shon HK, Kim YH, Lee KA (2014) Quality characteristics of bean sprouts with different Namulkong cultivars. Korean J Food Cookery Sci, 30, 340-350

4. Cho KM, Lee JH, Yun HD, Ahn BY, Kim H, Seo WT (2011) Changes of phytochemical constituents (isoflavone, flavanols, and phenolic acids) during Cheonggukjang soybeans fermentation using potential probiotics Bacillus subtilis CS90. J Food Compos Anal, 24, 402-410

5. Choi SK, Cha JH, Park KH (2013) Quality characteristics of bechamel sauce with different ratios of soy milk to milk. J East Soc Diet Life, 23, 61-68

6. Lee JH, Lee BW, Kim BL, Kim HT, Ko JM, Baek IY, Seo WT, Kang YM, Cho KM (2013) Changes in phenolic compounds (isoflavone and phenolic acids) and antioxidant properties in high-protein soybean (Glycine max L., cv. Saedanbaek) for different roasting conditions. J Korean Soc Appl Biol Chem, 56, 605-612

7. Yang M, Kwak JS, Jang SR, Jia YN, Park IS (2013) Antioxidant activity of soybean yogurt added to tomato extract by Bacillus subtilis and Lactobacillus plantarum Korean J Food Nutr, 26, 280-286

8. Cho KM, Ha TJ, Lee YB, Seo WD, Kim JY, Ryu HW, Jeong SH, Kang YM, Lee JH (2013) Soluble phenolics and antioxidant properties of soybean (Glycine max L.) cultivars with varying seed coat colours. J Funct Foods, 5, 1065-1076

9. Ewe JA, Wan-Abdullah WN, Alias AK, Liong MT (2012) Bioconversion of isoflavones and the probiotic properties of the electroporated parent and subsequent three subcultures of Lactobacillus fermentum BT 8219 in biotin-soymilk. J Microbiol Biotechnol, 22, 947-959

10. Bae HC, Nam MS (2005) Fermentation properties of the mixed yogurt prepared with bovine milk and soybean milk. Korean J Food Sci Anim Resour, 25, 483-493

11. Hwang CE, Ahn MJ, Lee HY, Lee BW, Kim HT, Ko JM, Baek IY, Seo WT, Cho KM (2014) Potential probiotic Lactobacillus plantarum P1201 to produce soy-yogurt with enhanced antioxidant activity. Korean J Food Sci Technol, 46, 556-565

12. Hwang CE, Haque MA, Lee JH, Ahn MJ, Lee HY, Lee 
BW, Lee YY, Lee CW, Kim BJ, Park JY, Sim EY, Lee DH, Ko JM, Kim HT, Cho KM (2016) Changes in phytoestrogen contents and antioxidant activities during fermentation of soybean-powder milks prepared from different soybean cultivars by Lactobacillus plantarum P1201. Korean J Microbiol, 52, 202-211

13. Lee JH, Kim B, Hwang CE, Haque MA, Kim SC, Lee CS, Kang SS, Cho KM, Lee DH (2018) Changes in conjugated linoleic acid and isoflavone contents from fermented soymilks using Lactobacillus plantarum P1201 and screening for their digestive enzyme inhibition and antioxidant properties. J Funct Foods, 43, 17-28

14. Hwang CE, Haque MA, Lee JH, Joo OS, Kim SC, Lee HY, Um BS, Park KS, Cho KM (2018) Comparison of $\gamma$-aminobutyric acid and isoflavone aglycone contents, to radical scavenging activities of high-protein soybean sprouting by lactic acid fermentation with Lactobacillus brevis. Korean J Food Preserv, 25, 7-18

15. Joo OS, Hwang CE, Hong SY, Sin EC, Nam SH, Cho KM (2018) Antioxidative and degestion enzyme inhibitory activity of Ganoderma lucidum depends on the extraction solvent. Korean J Food Preserv, 25, 124-135

16. Cho KM, Ahn BY, Seo WT (2008) Lactic acid fermentation of Gamju manufactured using medicinal herb decoction. Korean J Food Sci Technol, 40, 649-655

17. Hou JW, Yu RC, Chou CC (2000) Changes in some components of soymilk during fermentation with bifidobacteria. Food Res Int, 33, 393-397

18. Zhao D, Shah NP (2014) Effect of tea extract on lactic acid bacteria growth, their cell surface characteristics and isoflavone bioconversion during soymilk fermentation. Food Res Int, 62, 877-885

19. Marazza JA, Nazareno MA, de Giori GS, Garro MS (2012) Enhancement of the antioxidant capacity of soymilk by fermentation with Lactobacillus rhamnosus. J Funct Foods, 4, 594-601

20. da Silva LH, Celeghini RMS, Chang YK (2011) Effect of the fermentation of whole soybean flour on the conversion of isoflavones from glycosides to aglycones. Food Chem, 128, 640-644

21. Lee MY, Yoo MS, Whang YJ, Jin YJ, Hong MH, Pyo
YH (2012) Vitamin C, total polyphenol, flavonoid contents and antioxidant capacity of several fruit peels. Korean J Food Sci Technol, 44, 540-544

22. Prior RL, Wu X, Schaich K (2005) Standardized methods for determination of antioxidant capacity and phenolics in foods and dietary supplements. J Agric Food Chem, 53, 4290-4302

23. Lee JH, Cho KM (2012) Changes occurring compositional components of black soybeans maintained at room temperature for different storage periods. Food Chem, 131, 161-169

24. Kim YH, Lee JH, Lee YS, Yun HT (2006) Antioxidant activity and extraction efficiency of anthocyanin pigments in black colored soybean. Korea Soybean Dig, 23, 1-9

25. Kong JM, Chia LS, Goh NK, Chia TF, Brouillard R (2003) Analysis and biological activities of anthocyanins. Phytochem, 64, 923-933

26. Tsangalis D, Ashton JF, Mcgill AEJ, Shah NP (2002) Enzymic transformation of isoflavone phytoestrogens in soymilk by $\beta$-glucosidase-producing bifidobacteria. J Food Sci, 67, 3104-3113

27. Kim JH, Hwang CE, Lee CK, Lee JH, Kim GM, Jeong SH, Shin JH, Kim JS, Cho KM (2014) Characteristis and antioxidant effect of garlic in the fermentation of Cheonggukjang by Bacillus amyloliquefaciens MJ1-4. J Microbiol Biotechnol, 24, 959-968

28. Zhao D, Shah NP (2014) Changes in antioxidant capacity, isoflavone profile, phenolic and vitamin contents in soymilk during extended fermentation. LWT-Food Sci Technol, 58, 454-462

29. Rodriguez-Roque MJ, Rojas-Grau MA, Elez-Martinez P, Martin-Belloso O (2014) In vitro bioaccessibility of health-related compounds from a blended fruit juice-soymilk beverage: Influence of food matrix. J Funct Foods, 161-169

30. Blois MS (1958) Antioxidant determinations by the use of stable free radical. Nature, 18, 1199-1200

31. Hwang CE, Seo WY, Cho KM (2013) Enhanced antioxidant effect of black soybean by Cheonggukjang with potential probiotic Bacillus subtilis CSY191. Korean J Microbiol, 49, 391-397 